\title{
Calculating Grazing Intensity for Maximum Profit on Ponderosa Pine Range in Northern Arizona
}

\section{HENRY A. PEARSON}

Highlight: The profit formula is based on forage production, digestibility and utilization, animal weight and daily gain, costs per animal day, and beef prices. Rangeland producing 500-1,000 lb forage per acre would produce maximum profit with moderate utilization.

Grazing experiments have indicated that, for a few years, heavy grazing gives maximum cattle gains per acre and greatest profits. With prolonged heavy grazing, however, herbage production, beef production, and profits decline. Light grazing usually gives maximum gain per animal but is not often economically feasible. Correct range use most likely lies between maximum gain per animal and maximum short-term return per acre (Stoddart and Smith, 1955).

The objectives of this study were (1) to determine the effects of various grazing intensities on yearling cattle gains, and (2) to determine the grazing intensity which produces maximum profits. This work did not consider the effects on sustained herbage production nor resultant range condition.

Research reported here was conducted when the author was range scientist, Rocky Mountain Forest and Range Experiment Station, U.S. Department of Agriculture, Forest Service, at Flagstaff, in cooperation with Northern Arizona University. He currently is principal range scientist, Southern Forest Experiment Station, Pineville, Louisiana. The Rocky Mountain Station's headquarters is maintained at Fort Collins, in cooperation with Colorado State University.
The study area was a ponderosa pine (Pinus ponderosa Laws.) range near Flagstaff, Ariz., which was described in detail by Pearson and Jameson (1967). Arizona fescue (Festuca arizonica Vasey), mountain muhly (Muhlenbergia montana (Nutt.) Hitchc.), bottlebrush squirreltail (Sitanion hystrix (Nutt.) J. G. Smith), and sedge (Carex geophila Mackenz.) comprised the major portion of the herbaceous vegetation. Forty-five pairs of $9.6-\mathrm{ft}^{2}$ plots (one caged, one uncaged) were located in each of seven study pastures for measuring herbage production and percent forage utilization.

Yearling cattle grazed each pasture for a 4-month season, June through September, from 1963 to 1967 . Water and salt were manipulated to provide relatively uniform grazing throughout each pasture. The animals were weighed individually at the beginning and end of each grazing season. Forage utilization varied between $5 \%$ and $65 \%$ through the years due to variations in cattle numbers and forage production. This wide range in forage utilization provided an opportunity to evaluate the effects of different grazing intensities on beef gain per animal and economic returns.

\section{Cattle Gains}

Average daily gain per head of yearling cattle was linearly related to percent utilization. The simple regression equation was:

$$
\mathrm{g}=1.392-0.015 \mathrm{U}
$$

where $U$ is percent utilization and $g$ is pounds of daily animal 
gain. Although the coefficient of determination was quite low $(0.35)$, this relationship of cattle gain and grazing intensity is similar to results from studies on crested wheatgrass pastures in northern New Mexico (Springfield, 1963) and on ponderosa pine range in Colorado (Johnson, 1953; Smith, 1967). Adding forage production in a multiple regression analysis of average daily gains nearly doubled the coefficient of determination (0.61) compared to percent utilization alone. The multiple regression equation was:

$$
\mathrm{g}=1.198-0.186 \mathrm{U}+0.00047 \mathrm{P}
$$

where $P$ is pounds of forage produced per acre. Highest gains per animal were obtained on high forage-producing ranges under light grazing. But highest gain per animal does not necessarily mean maximum profits. Cost and return of gains per unit area must also be considered in formulating the most profitable grazing levels.

\section{Economic Implications}

Profit maximization involves a comparison of total costs with total receipts at various outputs or grazing levels. To obtain an economic comparison on ponderosa pine range, forage utilization can be analytically evaluated to determine use levels that provide maximum profits. Heavy grazing demands a higher investment than light or moderate grazing, since more animals are required. Although the investment is least with light grazing, the returns are also less than from intermediate or higher levels.

For profit analysis, costs from grazing National Forest or private lands were estimated to be about $\$ 0.10$ per yearling animal day, and the selling price of beef was determined to be about $\$ 0.25$ per pound. The cost estimate was based on data which compared public and private costs per animal unit month (Cliff, 1969). Costs from grazing were $\$ 4.54$ per animal unit month, or $\$ 0.15$ per animal unit day, or about $\$ 0.10$ per yearling animal day. Basically profits were equal to the total returns minus the total costs; however, several considerations are used to develop the final profit equation:

$$
\text { Profit }=\text { TR }- \text { TC }
$$

where $T R$ is total return per acre and $T C$ is total cost per acre;

$$
\mathrm{TR}=(\mathrm{R})(\mathrm{g})(\mathrm{T})
$$

where $R$ is price per $\mathrm{lb}, g$ is $\mathrm{lb}$ gain per day, and $T$ is yearling animal days per acre;

$$
\mathrm{TC}=(\mathrm{C})(\mathrm{T})
$$

where $C$ is cost per yearling day;

$$
\mathrm{T}=\frac{\mathrm{DA}}{\mathrm{DD}}
$$

where $D A$ is digestible forage consumed per acre and $D D$ is digestible forage consumed per yearling day. Consequently, these expressions are integrated into the following equation form:

$$
\begin{gathered}
\text { Profit }=(\mathrm{R})(\mathrm{g}) \frac{\mathrm{DA}}{\mathrm{DD}}-(\mathrm{C}) \frac{\mathrm{DA}}{\mathrm{DD}} \\
\text { or } \\
\text { Profit }=\frac{\mathrm{DA}}{\mathrm{DD}}(\mathrm{Rg}-\mathrm{C}) \\
\text { or } \\
\text { Profit }=\frac{(\mathrm{P} \cdot \mathrm{D} \cdot \mathrm{U})(0.25 \mathrm{~g}-0.10)}{0.033 \mathrm{w}^{3 / 4}(1+0.479 \mathrm{~g})}
\end{gathered}
$$

where $P$ is forage production in pounds per acre, $D$ is percent in vitro forage digestibility, $U$ is percent utilization, $g$ is pounds of daily animal gain (from equation 2), and $w$ is mean animal body weight. The denominator determines $D D$, or the digestible forage consumed per yearling day (Pearson, 1972), while the left portion $(P \cdot D \cdot U)$ of the numerator determines $D A$, or the digestible forage consumed per acre. The right portion of the numerator determines the returns and costs per animal day grazed.

To find the percent utilization that produces maximum benefits, set the derivative of the profit equation (equation 9) equal to zero. For example, percent utilization for maximum profit from an Arizona fescue-mountain muhly range producing $500 \mathrm{lb}$ forage per acre with an average $54 \%$ digestibility coefficient (Pearson, 1964) and grazed by 500-1b yearling cattle, is calculated as follows:

$$
\frac{\mathrm{d}}{\mathrm{U}} \frac{(500)(.54) \mathrm{U}(0.25 \mathrm{~g}-0.10)}{0.033(500)^{3 / 4}(1+0.479 \mathrm{~g})}=0
$$

The range is grazed most economically at $30 \%$ utilization. Range producing $1,000 \mathrm{lb}$ forage per acre would be grazed most economically at $38 \%$. Both grazing intensities on Arizona fescue-mountain muhly range would be considered moderate, and would not adversely affect long-term forage production, which in most years will exceed $500 \mathrm{lb}$ per acre, air dry under an open forest canopy.

Other variables of concern to the cattle industry are the selling price of beef and cost to graze animals. If the selling price goes up, then the utilization level for maximum profits increases slightly. On the other hand if cattle maintenance costs go up, the utilization level goes down. If both selling price of beef and cost per animal day increase proportionately, then the utilization level for maximum profits remains the same. For example, let's examine and make comparisons for the range producing $500 \mathrm{lb}$ forage per acre. If the selling price of beef was $\$ 0.30$ instead of $\$ 0.25$, then maximum profits would be attained at a grazing intensity of $32 \%$. If the costs per animal day were to increase to $\$ 0.12$, then maximum profits would be attained at the $28 \%$ grazing level. If both selling price and cost were increased by $20 \%$, then the grazing level should remain at $30 \%$ for maximum profits.

\section{Literature Cited}

Cliff, Edward P. 1969. Statement: Review of grazing fees. p. 121-126. In Hearings, Subcomm. Public Lands of Comm. on Inter. \& Insular Aff., House of Represent., U.S. Congr., 91st, 1st Sess. Ser. 91-1. $498 \mathrm{p}$.

Johnson, W. M. 1953. Effect of grazing intensity upon vegetation and cattle gains on ponderosa pine-bunchgrass ranges of the Front Range of Colorado. U.S. Dep. Agr. Circ. 929. 36 p.

Pearson, Henry A. 1964. Studies of forage digestibility under ponderosa pine stands. Soc. Amer. Forest. Proc. 1964:71-73.

Pearson, Henry A. 1972. Estimating cattle gains from consumption of digestible forage on ponderosa pine range. J. Range Manage. $25: 18-20$.

Pearson, Henry A., and Donald A. Jameson. 1967. Relationship between timber and cattle production on ponderosa pine rangeThe Wild Bill Range, U.S. Dep. Agr., Forest Serv., Rocky Mt. Forest and Range Exp. Sta., Fort Collins, Colo. 10 p.

Smith, Dwight R. 1967. Effects of cattle grazing on a ponderosa pinebunchgrass range in Colorado. U.S. Dep. Agr. Tech. Bull. 1371. 60 p.

Springfield, H. W. 1963. Cattle gains and plant responses from spring grazing on crested wheatgrass in northern New Mexico. U.S. Dep. Agr. Prod. Res. Rep. 74.46 p.

Stoddart, Laurence A., and Arthur D. Smith. 1955. Range management. Ed. 2, 433 p. McGraw-Hill Book Co., Inc., New York. 